Arhe XVI, 32/2019

UDK 165.741 Peirce C. S.

DOI https://doi.org/10.19090/arhe.2019.32.199-217

Originalni naučni rad

Original Scientific Article

\author{
MILENA KARAPETROVIĆ ${ }^{1}$ \\ Univerzitet u Banjoj Luci, Filozofski fakultet
}

\title{
NASLJEĐE METAFIZIČKOG KLUBA: PRAGMATIZAM ČARLSA SANDERSA PERSA
}

Sažetak: Pragmatizam kao filozofski pravac obično je na marginama interesovanja u okviru evropske kontinentalne filozofije. Najćešće se interpretira uopšteno imajući u vidu glavno načelo o korisnosti i posljedicama ideja, te se označava kao antimetafizičko i pojednostavljeno razumijevanje filozofije. Osim toga, za neke predstavnike, s obzirom na širinu njihovog obrazovanja i zanimanja, glavni naučni doprinos se vezuje za druge oblasti. Kod Vilijama Džejmsa to je psihologija, a kod Džona Djuija - pedagogija. U potpunosti na marginama ostaje djelo Čarlsa Sandersa Persa. Cilj ovog teksta je da pokaže da su razlozi zanemarivanja Persovog rada dobrim dijelom uslovljeni i kontekstom u kome nastaje njegova filozofija. Zato je neophodno fokus staviti na sljedeće teme: razvoj američke filozofije i nastanak pragmatizma, ključna određenja pragmatizma u Persovim spisima, osnovne razlike između radikalnog empirizma, pragmaticizma i instrumentalizma.

Ključne riječi: pragmatizam, pragmaticizam, metafizičko/antimetafizičko, Pers, ideja, posljedica

\section{UVOD}

Filozofski doprinos Čarlsa Sandersa Persa (Charles Sanders Peirce, 1839 - 1914) tokom dvadesetog vijeka posebno se aktuelizuje kroz razvoj semiologije, odnosno semiotike kako je on originalno naziva. I pored toga Persov cjelovit filozofski opus obično ostaje na marginama (evropskih) filozofskih udžbenika i pregleda istorije filozofije. U tekstu

\footnotetext{
${ }^{1}$ E-mail adresa autorke: milena.karapetrovic@ @ff.unibl.org
} 
što slijedi nije moguće napraviti sistematičan i detaljan pregled svih glavnih tema filozofije ovog predstavnika pragmatizma, već je namjera da se istaknu razlozi zanemarivanja Persove filozofije. U prvom poglavlju daje se kratki pregled američke filozofije u drugoj polovini 19. vijeka sa akcentom na nastanak pragmatizma. U okviru toga je i osvrt na odnos američkih filozofa prema tradiciji filozofije, posebno prema metafizici. U drugom poglavlju razmatraju se osnovni Persovi stavovi o razlozima da se uvede novi pravac u filozofiji, da se napravi otklon od skepticizma i da se ponovo raspravi pitanje odnosa mišljenja i stvarnosti. U trećem poglavlju namjera je da se istaknu glavne razlike između Vilijama Džejmsa (William James), Čarlsa S. Persa i Džona Djuija (John Dewey), posebno kada je riječ o definisanju i okvirima pragmatizma.

Od samog početka filozofija se razvija u prostoru koji presijeca svijet ideja i svijet stvarnosti. Okrenutost prema idealnom i nastojanje da se empirijsko iskoristi tek kao osnova za formiranje apstraktnih pojmova glavni je tok $\mathrm{u}$ kome se smješta najveći dio filozofskih pravaca. Usmjerenost ka stvarnosnom više nego ka idealnom - kako bi se svijet, ljudska bića i realnost razumjeli u njihovoj punoći - za pojedine filozofe moguća je jedino odbijanjem ili kritikovanjem metafizičkog kao glavnog obilježja filozofije. Izgradnja vlastitog puta mišljenja sa pozicija stvarnosnog, dalje od ontoloških fundamentalnih postavki, znači i stalno preispitivanje vlastite pozicije unutar filozofije. Primjera radi možemo spomenuti one koji najbolje oslikavaju te filozofske prijepore i nesaglasnosti kao što su predstavnici i predstavnice marksističke filozofije, feminističke filozofije, praktične filozofije, a na tom popisu neizostavni su i predstavnici pragmatizma.

Istovremeno radikalni iskoraci unutar ovih posebnih filozofskih krugova među predstavnicima tih pravaca proizvode i svojevrsno izopštavanje i marginalizaciju na suprotan način. Ako se neki/a od tih filozofa i filozofkinja i u najmanjoj mjeri bave i onim što bi se moglo opisati kao „tradicionalna“ filozofija bivaju označeni kao „metafizičari“. Vrijednosni sudovi o mjestu i značaju pojedinih filozofa i filozofkinja $u$ okviru same filozofije često su određeni i pitanjem prostora u kome se odvija filozofiranje. Onaj najsigurniji prostor ostaje akademski, ali jedan manji dio filozofa, vlastitim izborom ili spletom okolnosti, ostaje izvan 
tog kruga. Samim tim češće mogu biti podvrgnuti kritici, posebno kada je riječ o metodologiji i izboru tema kojima se bave. Sve ove tri prethodno navedene odrednice, koje utiču koja pozicija će biti dodijeljena nekom od mislilaca i misliteljki u oblasti filozofije, upravo se pokazuju na primjeru Čarlsa S. Persa. ${ }^{2}$

\section{PRAGMATIZAM I FILOZOFIJA AMERICANA}

Da bi se sagledao značaj Persovih stavova, kako za modernu filozofiju tako i za teoretske obrasce uticajne u doba savremenosti, neophodno je predočiti razloge smještanja njegovih djela izvan glavnog filozofskog toka. Dio tih odgovora pronalazimo i u okviru opšteg razmatranja o mjestu i ulozi pragmatizma kao filozofskog pravca. Razumijevanje nastanka pragmatističke filozofije u pravom svjetlu moguće je sagledati kada imamo u vidu: 1) da se filozofija u Sjedinjenim Američkim Državama značajnije razvija u 19. vijeku; 2) da se tek od doba razvoja pragmatizma intenzivno počinju razvijati američki univerziteti; 3) da posebno na početku postoje odstupanja od evropske filozofske terminologije i filozofskog metoda.

Kako naglašava jedan od prvih američkih istoričara filozofije Herbert Šnajder (Herbert W. Schneider): „Sve, otprilike, do 1820. bilo je

${ }^{2}$ C̆. S. Pers je studije završio na Harvardu (Harvard University), gdje se osim filozofijom, bavio i matematikom i hemijom. Kao predavač iz filozofskih predmeta radio je svega pet godina na Univerzitetu Džons Hopkins (Johns Hopkins University), a najveći dio života proveo je kao zaposlenik američke nacionalne službe za geodetska mjerenja (U. S. Coast and Geodetic Survey). Njegovi rukopisi, ostavljeni u arhivu Harvarda, decenijama su bili neistraženi i jednim dijelom i uništeni. Rezultat istrajnog rada kasnijih istraživača na njegovoj biografiji i bibliografiji rezultirao je bogatom kolekcijom u digitalnoj formi. Ovdje izdvajamo: The Peirce Edition Project, Writings of Charles S. Peirce, Indiana University-Purdue University Indianapolis (IUPUI), http://www.iupui.edu/ peirce/index.html, 05. 08. 2019.; Commens. Digital Companion to Charles S. Peirce, (ur.) Mats Bergman, Sami Paavola and João Queiroz, http://www.commens.org/home\#, 06. 08. 2019.; The Charles S. Peirce Society, koje je i izdavač časopisa - The Transactions of the Charles S. Peirce Society: A Quarterly Journal in American Philosophy, https://peircesociety.org/home; 06. 08. 2019. 
uobičajeno deliti filosofiju na prirodnu i moralnu; programi studija naših koledža odražavali su takvu podelu. Logika, metafizika i prirodna teologija, kao i retorika i kritika, obično su se predavali kao posebni predmeti i retko su bili obuhvaćeni pojmom filosofije. U kursevima prirodne filosofije studenti su izučavali prirodne nauke (onakve kakve su tada postojale).“3 ${ }^{\text {(3 }}$ To nam pokazuje da, u periodu neposredno prije razvoja pragmatističkog pravca, bavljenje filozofijom podrazumijeva posvećivanje samo određenim filozofskim temama izvan konteksta sveukupnog filozofskog znanja zavisno od dostupnosti literature iz Evrope i opredjeljenja samih predavača. Na taj način je otpočetka put ka filozofskim istraživanjima na američkim univerzitetima znatno drugačije utemeljen nego na evropskim univerzitetima. $\mathrm{S}$ jedne strane, to je uslovilo da govorimo o svojevrsnim slabim tačkama filozofije, koja se razvija na tlu $\mathrm{SAD}$, kao što je na primjer, nedovoljno temeljno i sistematično izučavanje istorije filozofije. S druge strane, to se može vidjeti kao preimućstvo i otvaranje puta ka drugačijem promišljanju bića i stvarnosti što vodi ka oslobođanju od postojećih obrazaca kako u sadržajnom tako i u formalnom smislu. Sve to imaće odraza i nekoliko decenija kasnije kada se bude uspostavljao pragmatizam.

Iako je evidentan uticaj novovijekovne filozofije i klasičnog njemačkog idealizma kod glavnih predstavnika pragmatizma - Vilijama Džejmsa, Čarlsa S. Persa i Džona Djuija, sve ih odlikuje upravo to što preuzimaju dijelove pojedinih filozofskih učenja i smještaju ih u nešto drugačiji kontekst što se može vidjeti kroz metodologiju i stil pisanja. Samim tim, i u svojim raspravama oni odstupaju od upotrebe ustaljenih značenja osnovnih filozofskih pojmova i time preispituju samu osnovu, ciljeve i domete filozofije. Decenijama poslije, pokušavajući da odgovori na pitanje na koji način je američka kultura prihvatila filozofiju i postoje li jasne specifičnosti onoga što bi se moglo nazvati američkom filozofijom, Daglas Anderson (Douglas Anderson) će iskoristiti termin Americana. Posebno će naglasiti da je jasno da je američkim filozofima, uprkos kritikama koje im se upućuju, posebno važno preplitanje iskustva

\footnotetext{
${ }^{3}$ Šnajder, H., Istorija američke filosofije, Obod, Cetinje 1971., str. 101.
} 
(ličnog/društvenog) i filozofskih stavova, jer to je „mjesto iz koga potiču i kome se uvijek vraćaju“. 4

Druga grupa razloga koja će znatno uticati na pozicioniranje Persove filozofije vezana je za sam pragmatizam i pitanje: ko je prvi i pravi predstavnik ove struje filozofskog mišljenja? Džejmsa će smatrati začetnikom ovog pravca, Djui će najviše doprinijeti popularizaciji i uticajnosti pragmatizma, a za Persa će ostati vezano da je ostavio (tek) ime i prvo određenje. Kako Džejms naglašava: „Ime je izvedeno iz grčke reči $\pi \varrho a ́ \gamma \mu a$ koja označava delanje, a od nje dolaze i naše reči „praksa“ i „praktičan“. Nju je prvi put uveo u filozofiju Čarls Pers 1878. godine.“5 Kasnije međusobne rasprave će usloviti da svaki od predstavnika ima svoju specifičnu odrednicu pragmatizma. Džejms će svoju verziju pragmatizma označiti kao radikalni empirizam, kod Djuija je riječ o intstrumentalizmu, dok Pers govori o pragmaticizmu. Osim toga, Pers će naglasiti da određenje termina pragmatizam prvenstveno treba tražiti $u$ Kantovoj (Immanuel Kant) filozofiji, a ne u antičkoj, te time uspostavlja jasnu razliku između svog i Džejmsovog razumijevanja termina pragma. U najkraćem, za Č. S. Persa to označava mišljenje koje je svrsishodno i vezano za iskustvo, dok prema V. Džejmsu to više vodi ka usmjeravanju na djelovanje u najopštijem smislu. ${ }^{6}$

Razumijevanje Persove filozofije, kao i stavova ostalih pragmatista, iz pozicije evropske kontinentalne filozofije bitno je određeno i pitanjem odnosa prema tada najvažnijoj filozofskoj disciplini - metafizici/ontologiji. Iako će za Persa put u filozofiju znatno biti ocrtan proučavanjem Kantove i Hegelove (Georg Wilhelm Friedrich Hegel) filozofije, na njegov način filozofskog istraživanja će znatno više uticati sam pristup filozofiji iz američke kulture, te jasno nastojanje da se istakne kritika ontološkog i metafizičkog. Ostaje zato pitanje: kako i na koji način je upravo Metafizički klub bio neka vrsta glavnog obilježja pragmatizma? Odgovor ponovo možemo tražiti u specifičnostima koje su

${ }^{4}$ Anderson, D. R., Philosophy Americana: Making Philosophy at Home in American Culture, Fordham University Press, New York 2006., str. 9.

${ }^{5}$ Џемс, В., Прагматизам, Дерета, Београд 1991., str. 34.

${ }^{6}$ Up. Mujkić, A., Kratka povijest pragmatizma, Hijatus, Zenica 2005., str. 11. 
odlikovale američke univerzitete još na samim njihovim počecima, a što je D. Anderson (Douglas R. Anderson) naglasio nazivom filozofija Americana. Jedno od glavnih obilježja kako onda tako i danas ${ }^{7}$, osim posvećenosti predavanjima i samostalnim istraživanjima, jeste stvaranje stalne prilike za razmjenu mišljenja i ideja, učešće u raspravama. Akademski klubovi, u kojima se okupljaju studenti, profesori, istraživači, zavisno od ličnih veza i zajedničkih tema, postaju i bitno mjesto da se kroz diskusiju jasnije ocrtaju vlastite ideje i kroz jedan zajednički napor dođe do onog što bi bio odgovarajući rezultat, pa čak i kada je riječ o filozofiji. O tome će posebno poslije govoriti Pers kada bude naglašavao važnost učešća naučne zajednice, a ne pojedinca, u procesu traganja za istinom.

Akademski klubovi u drugoj polovini 19. vijeka na američkim univerzitetima nisu rijetkost, ali među njima malo je filozofskih klubova, te će ovo spominjanje Metafizičkog kluba ostati posebno vezano za razvoj pragmatizma. ${ }^{8}$ Sam Klub će zapravo potrajati tek nekoliko mjeseci, ali će se njegovo postojanje pominjati i kod Džejmsa i kod Persa, jer će uobličavanje glavnih problema prvog i jedinog američkog filozofskog pravca biti skicirano tokom tih diskusija. ${ }^{9}$ Kako je u jednom od svojih

\footnotetext{
${ }^{7}$ Samo jedan od primjera na koji i danas način funkcionišu američki univerziteti: „Podsticaj Univerziteta Stanford pre svega se sastoji u tome da te kreativne procese zadrži u kampusu umesto da ih pusti da odu u druge gradove. To se obavlja na razne načine, ali pre svega kroz studentske klubove. Više od 650 takvih klubova registrovano je ovde." - Keze, K., Silicijumska dolina, Laguna, Beograd 2016., str. 75.

${ }^{8} \mathrm{U}$ krugovima istoričara pragmatizma Klub će imati i metaforičko značenje, ali biće i dio svojevrsnih legendi koje će se prenosti u pričama o pragmatistima. Tako će se, na primjer, jedan od najupućenijih u Persovu biografiju i bibliografiju u jednom kratkom tekstu pitati, da li je Klub uopšte postojao. Fisch., M. H., "Was There a Metaphysical Club in Cambridge? - A Postscript", Transactions of the Charles S. Peirce Society, Vol. 17, No. 2 (Spring, 1981), str. $128-130$.

${ }^{9} \mathrm{O}$ istoriji ovog kluba može se detaljan pregled naći u knjizi koji priređuju filozofi - Ryan, F. X., Butler, B. E., Good, J. A. (ur.), The Real Metaphysical Club: The Philosophers, Their Debates, and Selected Writings from 1870 to 1885, SUNY Press, Albany (NY) 2019., kao i u knjizi iz oblasti istorije kulture -
} 
tekstova zabilježio i Pers: „Bilo je to početkom sedamdesetih, kada smo se mi, jedna grupa mladih ljudi u Starom Kembridžu, nazivajući se poluironično, poluprkosno Metafizičkim klubom - jer agnosticizam se onda bio uobrazio i oholo mrštio na svaku metafiziku - sastajali, ponekad u mojoj radnoj sobi, ponekad u radnoj sobi Viljema Džemsa“"10.

Ovo usputno Persovo postavljanje veze između metafizike i agnosticizma čini se da pokazuje već u toj jednoj rečenici na koji način se pristupa metafizičkim pitanjima, ali to bi bio olako izrečen sud. Čitanjem brojnih filozofskih tekstova koje će predano arhivirati i uobličavati tek njegovi nasljednici, uočava se Persovo nastojanje da prvenstveno bude istraživač koji oblikovanju mišljenja pristupa kao nekoj vrsti eksperimenta ne težeći da ostvari jedinstvo, sklad i koherentnost $u$ iznošenju svojih stavova. „Filozofska misao Persova je veoma protivrečna - bio je to veliki naučni duh koji je snažno kritikovao metafizičke spekulacije i zalete i zahtevao naučnu jasnost i preciznost $u$ filozofiji, ali je to istovremeno bio i mislilac koji je i sam imao ogromne metafizičke ambicije i talenat spekulativca ništa manji od ambicija i talenta velikih sistematvoraca Platona, Kanta, Hegela.“. ${ }^{11}$

I pored jasnog nastojanja da idejama udahne život i čvrsto ih poveže sa stvarnošću, ali ne banalno kako to površni kritičari i slabi poznavaoci pragmatizma žele vidjeti, za Persa se može reći da je filozof koji ne odbacuje metafiziku u potpunosti već se kritički bavi metafizikom. Naravno, treba naglasiti da je to prije fragmentarno i nezavršeno nego sistematično, te možemo lako pokazati kako u tom pokušaju protivrječi sam sebi više nego drugim filozofima. Usljed toga i interpretatori Persovih koncepcija suočavaju se sa problemom kako ga uopšte pravilno vrednovati i u kom kontekstu. Po Umbertu Eku (Umberto Eco), koji se prvenstveno bavi semiologijom/semiotikom, ostaje problem razumijevanja Persovog opšteg koncepta usljed ukrštanja različitih perspektiva: „Izvesno je da, ukoliko je čovek ne tumači u semiotičkom

Menand, L., The Metaphysical Club: A Story of Ideas in America, Farrar, Straus, and Giroux, New York 2001.

${ }^{10}$ Pers, Č. S., Izabrani spisi. O pragmatizmu i pragmaticizmu, BIGZ, Beograd 1993., str. 271 - 2. (Peirce: CP 5.12)

${ }^{11}$ Životić, M., Pragmatizam i savremena filozofija, Nolit, Beograd 1966., str. 19. 
ključu, Persova metafizika i kosmologija ostaju nerazumljive, ali isto bi trebalo da se kaže i za njegovu semiotiku u odnosu na njegovu kosmologiju.“12 U tom smislu Metafizički klub, iako tek ,ironična“ bilješka u istoriji pragmatizma, ostavlja znatnog odjeka u Persovom djelu više nego kod drugih predstavnika ovog pravca.

\section{O ANTISKEPTICIZMU I POSLJEDICAMA (NE)JASNOSTI IDEJA}

Kao glavno načelo ne samo Persove filozofije, već i pragmatizma kao pravca, na prvom mjestu će se uvijek navoditi njegova maksima: „razmotrite kakve posledice, za koje bi se moglo zamisliti da imaju praktičnog značaja, mi zamišljamo da ima predmet naše zamisli. Dakle, naša zamisao tih posledica predstavlja svu našu zamisao predmeta. “13 $\mathrm{Da}$ bi mogao predočiti kako zamišljamo predmet i kako djelovati razmišljajući o posljedicama, Pers se usmjerava na dva cilja istraživanja: prvo, „kako učiniti naše ideje jasnim“14 i, drugo, kako ih sagledati okrenuti prema budućnosti. Iako na temelju proučavanja djela iz logike možemo stvoriti predstavu da je pitanju jasnosti i razgovjetnosti posvećen najveći dio rasprava $\mathrm{i}$ da je riječ o nečemu što možemo smatrati razrješenim, Pers će naglašavati da nas upravo to može voditi u zabludu, te glavni cilj mora biti uspostavljanje novih puteva istraživanja u filozofiji. Imati svijest o toj zabludi nije dovoljno, već je neophodno da budemo okrenuti ka onom šta namjeravamo i šta činimo dok nastojimo da obavimo smislene radnje imajući od početka u vidu i njihove posljedice. Pri tome, u pragmatizmu (posebno kod Persa i Djuija, kasnije i u neopragmatizmu) biće naznačeno da se to djelovanje i posljedice prvenstveno odnose na opšte, zajednicu, kolektivni i zajednički doprinos nauci i društvu. Upravo će to insistiranje na posljedicama naših (i misaonih) djelovanja voditi ka tome da se pragmatizam u najvećem broju pregleda istorija filozofije i udžbenika iz filozofije (posebno u evropskom

\footnotetext{
${ }^{12}$ Eko, U., Kant i kljunar, Paideia, Beograd 2000, str. 97.

${ }^{13}$ Pers, Č. S., Izabrani spisi, str. 174 - 175. (Peirce: CP 5.402)

${ }^{14}$ Naziv članka objavljenog 1878 . godine.
} 
prostoru) svede tek na govor o pukoj korisnosti kao glavnom stavu pragmatističke filozofije. $^{15}$

Temeljni Persov motiv je da, kako naglašava, misli učini jasnim, ali za razliku od Dekarta (René Descartes), to nije moguće idući putem sumnje već upravo suprotno - tragajući za osnovama vjerovanja. Vjerovanje se ovdje ne shvata kao osnova religioznog stava, već služi za preispitivanje osnovnih logičkih načela i razumijevanje procesa mišljenja koji nas vode ka zaključcima kao elementima za izgradnju nauka. Vjerovanje možemo opisati i predočiti kao „misao u mirovanju“ i „stadijum mentalne akcije“"16; „naziv onoga što je suprotno sumnji“ $i$ što ne može da se „odnosi na stupnjeve izvesnosti niti na prirodu stava koji se smatra istinitim““17; kao jednu od „navika duha koja neizostavno traje neko vreme ${ }^{\text {“18. }}$. Iako nam se čini da tradicionalna logika ostavlja sigurne i provjerene puteve ka (objektivnom) zaključivanju, značajno je ponovo preispitati dijelove tog puta tako što ćemo se vratiti na sam početak i odgovoriti na jednostavna pitanja o tome kako zapravo utvrđujemo zaključke i zašto sa sigurnošću tvrdimo da je riječ o zaključku kod koga treba da se zadržimo. Za Persa, vjerovanje je to koje nam može poslužiti kao daleko bolji alat za razvijanje mišljenja od sumnje, jer nas drži dalje od razdražujućeg nemira, nedoumica i omogućava nam da steknemo kako jasniju i precizniju sliku o svijetu tako i da budemo svjesniji naših individualnih aktivnosti kao onog što predstavlja dio kolektivnog duha $\mathrm{i}$ djelovanja naučne ili zajednice uopšte.

Osnova kritike Dekartove metode prvenstveno je izgrađena na stavu da nas skepticizam može navesti da dođemo do forme jasne ideje, ali ostaje pitanje da li je ta ideja zaista jasna ili je samo ona koja se prva

\footnotetext{
15 Iako će se, s obzirom na svoju težnju da promjeni svijet a ne samo da ga interpretira, marksistička filozofija činiti bliska pragmatizmu, kritike dolaze i sa ove pozicije: „Pragmatistički oblik teorijske mimeze postojećoj stvarnosti ide uz nekritičku veru u svemoć naučnih instrumenata da urede svet na uman način, uz pridavanje samom instrumentu karakteristike posljednje instance smisla stvarnosti.“ - Životić, M., Pragmatizam i savremena filozofija, str. 11.

${ }^{16}$ Pers, Č. S., Izabrani spisi, str. 171. (Peirce: CP 5.397)

${ }^{17}$ Ibid., str. 198. (Peirce: CP 5.416)

${ }^{18}$ Ibid., str. 199. (Peirce: CP 5.417)
} 
pojavila poslije prevelikog iscrpljivanja sumnjom. Sumnja „podstiče duh na aktivnost“19, ali ona istovremeno unosi nemir i predstavlja „nelagodno i nezadovoljavajuće stanje ${ }^{\text {‘20 }}$ koji se želi što prije prevazići, te upravo može voditi ka želji da što prije okončamo proces koji treba da se završi zaključivanjem kako bismo se vratili u sigurno stanje mirovanja. Zato Pers smatra, da prije nego što počne da kritikuje tradicionalne filozofske metode i prije nego što počne da gradi novu metodu, treba razmotriti kako se izgrađuje vjerovanje u najopštijem smislu i zašto je ono važno kako za individuu tako i za društvo, odnosno za stvaranje vrijednosti ka kojima će se stremiti. Osim naučne metode, mogu se razmotriti načini na koji se dolazi do vjerovanja putem upornosti, okretanjem prema autoritetu ili na apriorističkoj osnovi.

Razmotrimo li bazičnu potrebu ljudskog bića da djeluje bez pretjerane sumnje, na osnovu jednostavnog neupitnog viđenja svijeta, jasno je zašto se pojavljuje puko ponavljanje određenih uvjerenja ili kako Pers kaže „,instinktivna antipatija prema neodlučnom stanju duha, koja, preuveličavanjem, postaje strah od sumnje, nagoni ljude da se grčevito drže gledišta koja već zauzimaju“21. Način učvršćivanja vjerovanja konstantnim ponavljanjem osnova je na kojoj se dalje gradi metoda autoriteta. Strah individue od nesigurnosti života u sumnji povezuje se autoritativnim naredbama državnog aparata i ovo „spada među najvažnija sredstva kojima se podržavaju pravoverna teološka i politička učenja““. ${ }^{22}$ I jedan i drugi način učvršćivanja vjerovanja ipak se pokazuju nedovoljno snažnim da ljudski duh zadrže u mirovanju. Ovi načini postupanja tokom dužeg vremenskog perioda ili više ne pružaju adekvatne odgovore na nova pitanja koja se pojavljuju ili odgovori nemaju dovoljnu snagu da jačaju ranija ubjeđenja. I pored toga, oni ostaju značajni za proučavanje djelovanja individua u društvenim i političkim okvirima i mogu se razvijati nasuprot, u skladu ili paralelno sa metodama kojima

${ }^{19}$ Ibid., str. 169. (Peirce: CP 5.394)
${ }^{20}$ Ibid., str. 140. (Peirce: CP 5.371)
${ }^{21}$ Ibid., str. 144. (Peirce: CP 5.377)
${ }^{22}$ Ibid., str. 146. (Peirce: CP 5.379) 
izgrađujemo temelje racionalnog promišljanja svijeta. Pouzdanije odgovore možemo zato tražiti jedino u oblasti filozofije odnosno nauka.

Jedan od osnovnih stavova filozofije još od antičkog doba - o slaganju misli i stvari - oblikuje apriorističku metodu koje ne ostaje samo dio tradicionalne metafizike već čini razumsku pretpostavku za razvoj mišljenja. Ovdje se sumnja neće pojaviti kada nestane upornosti ili kada počnemo, uprkos svemu, preispitivati autoritet države, već sumnja narasta usljed mogućnosti da postoji više odgovora koji nas vode u različitim pravcima. Predavanje umskom više nego razumu, kao i idealnom prije nego realnom u jednom momentu presuđuje u korist nezaustavljivog skepticizma. Tako se čini da i ova metoda može biti pod udarom nekog „slučajnog i ćudljivog elementa“"23. Za Persa je prvenstveno važno da iz vida ne izgubimo ono realno, iskustveno, činjenično, ono što je moguće potvrditi. Naučna metoda najmanje može voditi ka sumnji, jer se bavi upavo realnim (stvarima); teško može voditi ka zabludama i gubljenju u oprečnim stavovima; pokazuje širinu svoje primjenjivosti; te svakom svojom primjenom pokazuje pouzdanost. U najkraćem, „mi možemo zaključivanjem da utvrdimo kako stvari realno i istinski stoje; i svaki čovek, ako ima dovoljno iskustva i ako dovoljno razmišlja o tome, doći će do jednog jedinog Istinitog zaključka“. ${ }^{24}$

Prema Persu, zablude u koje možemo zapasti, kada je riječ o jasnosti i razgovjetnosti ideja, zasnovane su prvenstveno na iluziji da se do jasnih ideja lako dolazi, da se one odmah kao takve uočavaju, da zaboravljamo da jasnost miješamo sa prepoznavanjem ideja koje smo već ranije upoznali i sa subjektivnim stavom o bliskošću sa datim idejama. Razgovjetnost ideja, prema tradicionalnoj logici, vezana je za njihovo definisanje odgovarajućom terminologijom. ${ }^{25}$ Tako ostajemo pri stavu da je naše poznavanje predstavljanja ideja zaokruženo i već utvrđeno ranijim filozofskim konceptima, te nije neophodno da se dalje bavimo tim pitanjem. To su početne tvrdnje za kritiku Dekartovog skeptičkog stava za koji Pers smatra da posebno na individualnom planu može voditi ka

\footnotetext{
${ }^{23}$ Ibid., str. 152. (Peirce: CP 5.383)

${ }^{24}$ Ibid., str, 154. (Peirce: CP 5.384)

${ }^{25}$ Up., Ibid., str. 163 - 164. (Peirce: CP 5.388 - 5.389)
} 
neproduktivnom intelektualnom životu i lutanju u začaranom krugu usljed nemogućnosti da se odredi razlika između jasnih i nejasnih ideja. Da bi se to izbjeglo nephodno je okrenuti se ka pitanju - na koji način funkcioniše naše mišljenje kada nastojimo da dođemo do jasnih ideja kako bismo bili sigurni da možemo ostati pri njihovoj odbrani, umjesto da se beskonačno krećemo putem skepticizma.

U procesu utvrđivanja jasnih ideja učvršćivanje vjerovanja, kao i skeptička metoda, samo po sebi nije lišeno iluzija i zabluda. Jedna od mogućih obmana je da, u nastojanju da što prije dođemo do rezultata, prihvatamo vlastite nejasne misli vjerujući da je to stvarna slika objekta, te stvorimo nepremostivu prepreku za prepoznavanje objekta onakvog kakav jeste. Druga obmana jeste zamjenjivanje mišljenja riječima koje izražavanju tu radnju ili odnos. ${ }^{26}$ Prema Persu, zaustavljanje toka mišljenja ipak nam više nego metodička skepsa omogućava da sagledamo razliku između onoga kako mislimo i o čemu mislimo. Dekartovski put nas ostavlja u sjeni velikog Ja, koji ne dopušta da vidimo jasno šta je sadržaj mišljenja, a šta je opis zadivljenosti samom aktivnošću Ja koje obavlja mišljenje. Da bismo zablude sveli na minimum, za Persa je djelotvornije ostati na putu vjerovanja, uz stalnu svijest o mogućim stranputicama, a glavni putokaz je imati u vidu upravo posljedice tih vlastitih zamisli, onako kako se tvrdi u maksimi. Na tom putu posljedice nisu ono na šta treba da se fokusiramo niti su najvažniji dio tog puta, one nam samo omogućavaju da sagledamo cjelovitu sliku i pokušamo što preciznije odgovoriti na pitanje - šta naše mišljenje uistinu jeste. Zato Pers smatra da je neophodno naglasiti da se ovdje ne radi o okrenutosti ka pukom praktičnom koje nas vodi dalje od filozofskog, već je riječ o pragmatičnom razumijevanju odnosa misli i stvarnosti, te je „najupadljivija odlika nove teorije bilo (...) upravo priznanje neraskidive veze između racionalnog saznanja (cognition) i racionalne svrhe (purpose) $^{627}$.

\footnotetext{
${ }^{26}$ Up., Ibid., str. 172. (Peirce: CP 5.398 - 5.399)

${ }^{27}$ Ibid., str. 193. (Peirce: CP 5.412)
} 


\section{PRAGMATISTI, NEOPRAGMATISTI I NOVI PRAGMATISTI}

U prethodnom poglavlju istaknute su samo neke od tema kojima se bavio Pers imajući prvenstveno u vidu njegovo određenje pragmatizma. Imenovanje, te definisanje opsega i sadržaja ovog filozofskog pravca samo su prve u nizu razlika između njegovih glavnih predstavnika. Za Vilijama Džejmsa metafizika je tek neka vrsta „magije“, življenja u iluziji i nastojanju da se dosegne ono božansko, te samim tim put koji ne vodi niti ka dostizanju istine niti mogućnosti da provjerimo rezultate vlastitih istraživanja. ${ }^{28}$ Kada je riječ o prethodnim pravcima $u$ istoriji filozofije, Džejms slijedi empirizam, a ključna disciplina od koje polazi može biti jedino logika. Zato pragmatizam prvo treba da se usmjeri na same načine i oblike istraživanja kako bi bio ,genetička teorija o onome što se podrazumeva pod istinom“ “29. Pri tome, poimanje istine vezuje se za problem usmjeravanja pragmatističkih istraživanja i preispituje se ne to koliko je istina odraz stvarnosti, već sama veza između misli i stvari. Ono što je takođe bitno za Džejmsa je pitanje adekvatnosti, koju moramo shvatiti potpuno drugačije - u kojoj mjeri je vezana za život, stvarnost i šta ona predstavlja ne samo u nekom opštem apstraktnom smislu, već i na individualnom nivou. Zato je važno prema istini ići stalno imajući u vidu iskustvo.

Džejms će naglasiti: „Istinitost jedne ideje nije postojano svojstvo, nerazdeljivo od nje. (...) Njezina tačnost je ustvari, događaj, zbivanje: naime, zbivanje njezinog proveravanja sebe, kao što je njezino potvrđivanje zbivanje overavanja. ${ }^{\text {‘30 }}$ Svoju filozofiju sam će odrediti kao radikalni empirizam, jer vodilja mora biti okrenutost samo i jedino ka onome što je neposredno doživljeno. Pragmatizam jeste teorija, ali prije svega, to je metod koji treba da vodi ka potpunom raskidu sa metafizikom, tako što će ukazati na nepotrebnost pretjeranog bavljenja metafizičkim sporovima. Ključni momenat provjere za neki metafizički problem jeste: da li i kakve posljedice ima na stvarnost, odnosno da li

\footnotetext{
${ }^{28}$ Uр., Џемс, В., Прагматизам, str. 37 - 38.

${ }^{29}$ Ibid., str. 44.

${ }^{30}$ Ibid., str. 117.
} 
uopšte utiče na naše živote? Cilj pragmatizma nije da ponudi odgovore, već da stvori uslove za drugačije promišljanje našeg odnosa prema idejama koje stvaramo i njihovog smještanja u polje stvarnosti. Po Džejmsu, glavni kriteriji na osnovu koga pragmatista treba da djeluje jeste - da sagleda šta je to ,što pristaje najbolje uz svaki deo života i ukalupljuje se u zajednicu zahteva iskustva, a da se ništa ne izostavi““. ${ }^{31}$

Kako je Džon Djui najuticajniji predstavnik pragmatizma, njegovo snažno isticanje praktičnog, kao onog koje se uvijek može i primjeniti u društvu, najviše je ostalo i zapamćeno. Tako se ovdje jasnije uočava razlika između pragmaticizma i instrumentalizma. „Ovaj stalni ritam praksa-teorija-praksa pokreće svaki aspekt Djuijevog intelektualnog djelovanja i možda objašnjava zašto su njegove teorije $\mathrm{i}$ dalje predmet diskusije, kritike, primjene i zašto su i dalje bitne u različitim akademskim i praktičnim oblastima. “32 Razlog za to je, što se Djui posebno bavio i pitanjima iz političke filozofije, ali i politike i demokratije, teorijom obrazovanja, ali i i učestvovao u reformama obrazovnog sistema, te će se njegovo uticaj (za razliku od Džejmsa i Persa) u većoj mjeri odraziti na razvoj američkog društva početkom dvadesetog vijeka. Iako ostaje pri osnovnim principima pragmatizma, Djui će kritikovati prethodno iznesene stavove o pragmatizmu zbog nemogućnosti da do kraja izvedu zamisao osnovnog pragmatističkog cilja kako ga on razumije, a to je da pokaže snagu kroz izvođenje reforme ili rekonstrukcije ${ }^{33}$, što je njegova osnovna misija i kad je riječ o filozofiji i kada je riječ o društvu. Sažet pregled Djuijeve kritike pragmatizma možemo pronaći u zbirci eseja pod nazivom Filozofija i civilizacija.

Djui inspiraciju prije pronalazi u prosvjetiteljstvu, nego u sholastici, empirizmu ili klasičnom njemačkom idealizmu, jer smatra da

\footnotetext{
${ }^{31}$ Ibid., str. 51.

${ }^{32}$ Hildebrand, D., "John Dewey", u The Stanford Encyclopedia of Philosophy (Winter 2018 Edition), Edward Zalta (ur.), 02. 08.2019. https://plato.stanford.edu/archives/win2018/entries/dewey/

33 Jedna od njegovih najpoznatijih filozofskih knjiga, nastala na temelju predavanja koja je održao u Japanu, upravo nosi naslov Reconstruction in Philosophy, u prevodu Asima Mujkića - Dewey, J., Rekonstrukcija u filozofiji, Buybook, Sarajevo 2004.
} 
su francuski filozofi 18. vijeka na najbolji način pokazali kako je moguće pratiti napredak nauke, njene rezultate $\mathrm{i}$ to primijeniti kako bi se mijenjalo i društvo i svijest ljudi. ${ }^{34}$ Sve to mora biti vezano za samo američko društvo i potrebe ljudi u tom društvu, bilo da se primijenjuje u svrhu individualnog razvoja, ili za stvaranje dobrobiti za cijelu zajednicu. Djui insistira na formiranju specifične američke filozofije. Za razliku od djelovanja prethodnika (biheviorista, neorealista, idealista) koji su bili usmjereni tek ka interpretaciji evropske filozofije, pragmatizam vidi kao novi original doprinos filozofiji. Tako instrumentalizam postaje i ostaje najprepoznatljivija varijanta pragmatizma.

Korisnim se ovdje čini skoro duhovit opis Ričarda Rortija (Richard Rorty): „Pragmatist pokušava da se brani govoreći da se može biti filozof ponašajući se anti-Filozofski, da je najbolji način da se 'stvari uklope' taj da se pobegne od spornih pitanja platonista i pozitivista i time odbace pretpostavke Filozofije. ${ }^{\text {‘35 }}$ To će svakako biti i jedan od razloga zašto pragmatizam ostaje izvan glavnih struja filozofije, pa čak i zašto kroz 20. vijek neće previše odgovarati ni američkoj kulturi i društvu već će primat od njega brzo uzeti analitička filozofija. Ona će se činiti kao jasna vodilja u mišljenju s obzirom da se služi čistom argumentacijom i nastojanjem da se stvari, biće i svijet precizno definišu kako bi se izbjeglo skretanje u ,pogrešnom“ pravcu - ka metafizičkim lavirintima. Za razliku od pragmatista, prvi analitički filozofi i ne pokušavaju da se suoče sa metafizičkim, oni ga jednostavno odbacuju. Pragmatisti odbacuju (tradicionalnu) filozofiju tako što se zapravo cijelo vrijeme bave metafizikom. Zato i ne iznenađuje da će u njihovim konceptima Rorti pronaći uporište za pokušaj premoštavanja jaza između anglosaksonske i kontinentalne evropske filozofije. Osim toga, uprkos brojnim slabostima, koje kritičari pronalaze kod glavnih predstavnika pragmatizma, ostaje vidljiv njihov filozofski uticaj. „Temeljna reinterpretacija tradicionalne razlike (uključujući i Kantovu) između teoretske filozofije koja uključuje logiku, metafiziku, epistemologiju, filozofiju nauke i druga polja i

\footnotetext{
${ }^{34}$ Dewey, J., "The Development of American Pragmatism" u Philosophy and Civilization, G. P. Putnam's Sons, New York 1931., str. 34 -35.

${ }^{35}$ Rorti, R., Konsekvence pragmatizma, Nolit, Beograd 1992., str. 53.
} 
praktične filozofije koja uključuje kako etiku tako i društvenu i političku filozofiju, trebala bi biti viđena kao ključni doprinos pragmatista metafilozofiji dvadesetog (i dvadeset prvog vijeka). ‘36

U ovom tekstu riječ je bila prije svega o filozofima koji stvaraju temelje pragmatizma, ali ovdje svakako treba napomenuti da se može govoriti i o filozofima (kao i teoretičarima iz drugih oblasti) u čijim radovima se u manjoj ili većoj mjeri prepoznaje usmjerenost ka pragmatizmu. Džejmsovo učenje nastavlja i nadopunjuje Ferdinand Šiler (Ferdinand Canning Scott Schiller) ističući u prvi plan odrednice kao što su humanizam i personalizam. Paralelno sa Djuievim instrumentalizmom svoj pragmatistički koncept razvija filozof, sociolog i psiholog Džordž Herbert Mid (George Herbert Mead) čiji će simbolički interakcionizam i socijalni biheviorizam imati znatnog uticaja na razvoj društvenih nauka u 20. vijeku. Na američkim univerzitetima pragmatističko učenje će veoma brzo zamijeniti i ostaviti u drugom planu analitička filozofija, ali će neki od predstavnika ove struje $u$ filozofiji biti svrstani $i$ među (neo)pragmatiste kao što su, na primjer, Vilard Van Orman Kvajn (Willard Van Orman Quine), Hilar Patnam (Hilary Putnam) i Donald Dejvidson (Donald Davidson).

Pragmatističku filozofiju će u punoj mjeri ponovo oživjeti Ričard Rorti. Uvažavajući rad pojedinih analitičara, ali praveći odmak od analitičkog pristupa filozofiji, Rorti će se prvenstveno baviti temama iz filozofije jezika, ali sada na tragu postmodernih/postrukturalističkih tendencija. Kako sam naglašava: „Neke od linija mišljenja podstaknute neo-pragmatističkom američkom filozofijom imaju dosta zajedničkih karakteristika sa postničeanskim evropskim filozofskim pravcima. To su pravci mišljenja koji me zapravo i najviše interesuju“. ${ }^{37}$ Vraćanje na pragmatizam će za još jednog savremeno američkog filozofa - Roberta Brandoma predstavljati tek poticaj za okretanje ka interpretacijama klasične evropske filozofije. Upravo ova dva filozofa će potaknuti da se obrazuje novi krug mislilaca koji će ih izrazito kritikovati zbog njihovog

\footnotetext{
${ }^{36}$ Pihlström, S. (ur.), The Continuum Companion to Pragmatism, Continuum, London, New York 2011., str. 100.

${ }^{37}$ Rorti, R., Konsekvence pragmatizma, str. 42.
} 
tumačenja prve američkoj filozofiji, te će se nazvati novim pragmatistima. Među najpoznatijim predstavnicima ovdje možemo izdvojiti filozofe/kinje: Suzan Hak (Susan Haack), Kristofera Hukveja (Christopher Hookway) i Šeril Misak (Cheryl Misak). ${ }^{38}$ Ponovno buđenje interesa za pragmatizam, koji neće biti samo osnova za građanje vlastite koncepcije, već će biti vraćanje izvorima, pa samim tim i svim predstavnicima klasičnog pragmatizma, biće prilika da se u većoj mjeri posveti pažnja i Persu, ne samo kao onom koji se spominje uz Džejmsa i Djuija.

\section{ZAVRŠNA RAZMATRANJA}

Kako je naglašeno na početku ovog rada, glavni cilj je bio da se predstavi kontekst i okolnosti, koje su uticale na to da jedan od predstavnika pragmatizma - Č. S. Pers neopravdano ostane izvan glavnih tokova filozofije. Kao što je je pokazano, dio razloga možemo tražiti u međusobnom (ne)razumijevanju američkih i evropskih filozofa. To se, prije svega odnosi, na percepciju i interpretaciju (tradicije) filozofije $u$ Sjedinjenim Američkim Državama, kao i nastojanje da se razvije originalni američki filozofski pravac što uslovljava i stvaranje drugačijih metodoloških okvira, pristupa problemima i filozofskog stila. Samim tim ponekad je komunikacija zaustavljena već na početku jednostavnim osporavanjem i zadržavanjem na suprotstavljenim pozicijama.

Uzme li se u obzir istorija razvoja akademske filozofije na američkim univerzitetima, može se uočiti brzo smjenjivanje trendova što je uticalo da pragmatizam i na tom prostoru bude brzo zamjenjen konkurentnijom i novijom analitičkom filozofijom, te decenijama ostaje na marginama istraživanja. Osim toga, unutar samog klasičnog pragmatizma otpočetka veća pažnja je usmjerena na rad Vilijama Džejmsa i Džona Djuija koji znatno duže djeluju u akademskim

\footnotetext{
${ }^{38}$ Up. Legg, C. and Hookway, C., „Pragmatism“, Edward N. Zalta (ur.), The Stanford Encyclopedia of Philosophy (Spring 2019 Edition), https://plato.stanford.edu/archives/spr2019/entries/pragmatism/, 25. 08. 2019.
} 
krugovima, nego na Persa koji bira nezavisnost u djelovanju i istraživanju. Samim tim pozivanje na kratko postojanje Metafizičkog kluba ovdje je upotrebljeno kako bi se prvenstveno označio njegov rad. Iako Persova uloga u razvoju savremene teorije o znakovima i simbolima ostaje neosporna, te je nezaobilazno njegovo spominjanje u okviru ove oblasti, ostaje pitanje u kojoj mjeri je bitno posvetiti se i ostalim temama i problemima kojima se ovaj filozof bavio. Obimna rukopisna zaostavština, sada dobrim dijelom i digitalizovana, tek posljednjih decenija pruža mogućnost za nova iscrpnija istraživanja njegovog doprinosa filozofiji.

\section{LITERATURA}

Anderson, D. R., Philosophy Americana: Making Philosophy at Home in American Culture, Fordham University Press, New York 2006.

Dewey, J, Rekonstrukcija u filozofiji, Buybook, Sarajevo 2004.

Dewey, J., "The Development of American Pragmatism" u Philosophy and Civilization, G. P. Putnam's Sons, New York 1931.

Џемс, В., Прагматизам, Дерета, Београд 1991.

Eko, U., Kant i kljunar, Paideia, Beograd 2000, str. 97.

Fisch., M. H., "Was There a Metaphysical Club in Cambridge? - A Postscript", Transactions of the Charles S. Peirce Society, Vol. 17, No. 2 (Spring, 1981)

Keze, K., Silicijumska dolina, Laguna, Beograd 2016.

Menand, L., The Metaphysical Club: A Story of Ideas in America, Farrar, Straus, and Giroux, New York 2001.

Mujkić, A., Kratka povijest pragmatizma, Hijatus, Zenica 2005.

Pers, Č. S., Izabrani spisi. O pragmatizmu i pragmaticizmu, BIGZ, Beograd 1993.

Pihlström, S. (ed.), The Continuum Companion to Pragmatism, Continuum, London, New York, 2011.

Rorti, R., Konsekvence pragmatizma, Nolit, Beograd 1992.

Ryan, F. X., Butler, B. E., Good, J. A. (ur.), The Real Metaphysical Club: The Philosophers, Their Debates, and Selected Writings from 1870 to 1885, SUNY Press, Albany (NY) 2019.

Šnajder, H., Istorija američke filosofije, Obod, Cetinje 1971.

Životić, M., Pragmatizam i savremena filozofija, Nolit, Beograd 1966. 
Hildebrand, D., "John Dewey", u The Stanford Encyclopedia of Philosophy (Winter 2018 Edition), Edward N. Zalta (ur.), 02. 08. 2019. https://plato.stanford.edu/archives/win2018/entries/dewey/>.

Legg, C. and Hookway, C., „Pragmatism“, Edward N. Zalta (ur.), u The Stanford Encyclopedia of Philosophy (Spring 2019 Edition), https://plato.stanford.edu/archives/spr2019/entries/pragmatism/, 25. 08. 2019.

\author{
MILENA KARAPETROVIĆ \\ University of Banja Luka, Faculty of Philosophy
}

\title{
THE HERITAGE OF THE METAPHYSICAL CLUB: THE PRAGMATISM OF CHARLES SANDERS PEIRCE
}

\begin{abstract}
Pragmatism as a philosophical movement/branch of philosophy is usually on the margins of interest within European (continental) philosophy. It is most commonly interpreted in general terms concerning its overriding principle of the usefulness and consequences of ideas and is referred to as an antimetaphysical and simplistic understanding of philosophy. Also, for some representatives, given the breadth of their education and occupation, major scientific contributions are related to other fields. With William James, it is psychology, and with John Dewey, it is pedagogy. Completely in the margins remains the work of Charles Sanders Peirce. This paper aims to show that the reasons for neglecting Peirce's work are largely conditioned by the context in which his philosophy originates. Therefore, it is necessary to focus on the following topics: the development of American philosophy and the emergence of pragmatism, the key determinations of pragmatism in Peirce`s writings, the basic differences between radical empiricism, pragmaticism, and instrumentalism.
\end{abstract}

Keywords: pragmatism, pragmaticism, metaphysical/anti-metaphysical, Peirce, idea, consequence

Primljeno: 6.8.2019.

Prihvaćeno: 2.11.2019. 